\title{
PEMBELAJARAN FISIKA MELALUI STRATEGI RECIPROCAL TEACHING DITINJAU DARI SIKAP ILMIAH TERHADAP HASIL BELAJAR KOGNITIF PESERTA DIDIK
}

\author{
Muhammad Satriawan \\ Dosen Prodi Pendidikan Fisika STKIP Bima \\ Email: satriawan.stkipbima@gmail.com
}

\begin{abstract}
Abstrak
Penelitian ini bertujuan untuk mengetahui ada tidaknya: (1) Perbedaan hasil belajar antara peserta didik yang diajar menggunakan strategi reciprocal teaching dengan peserta didik yang diajar menggunakan strategi konvensional. (2) Perbedaan hasil belajar antara peserta didik yang memiliki sikap ilmiah tinggi dan peserta didik yang memiliki sikap ilmiah rendah. (3) Interaksi antara strategi pembelajaran dengan sikap ilmiah terhadap hasil belajar. Sampel penelitian diambil 2 kelas dari 3 kelas X IPA SMAN 1 Langgudu berjumlah 115 peserta didik yang terbagi menjadi satu kelompok eksperimen dan satu kelompok kontrol, kelompok pertama diajar menggunakan strategi pembelajaran reciprocal teaching dan kelompok kedua diajar menggunakan strategi pembelajaran konvensional. Pengambilan data dilakukan dengan tehnik tes untuk hasil belajar kognitif dan angket untuk sikap ilmiah peserta didik. Jenis penelitian adalah quasi eksperimen dengan desain faktorial $2 \times 2$. Data dianalisis dengan menggunakan teknik analisis varians (ANAVA) dua jalan dengan bantuan program SPSS 20,0 for windows. Hasil analisis data pada taraf signifikan 0,05 dan $F_{\text {ratio }}=4$, menunjukkan bahwa: (1) nilai signifikan penggunaan strategi reciprocal teaching terhadap hasil belajar sebesar 0,935 dan $F_{\text {ratio }}=0,007$ lebih kecil dari $F_{\text {tabel }}=4$; (2) nilai signifikan sikap ilmiah peserta didik terhadap hasil belajar sebesar 0,000 dan $F_{\text {ratio }}=17,157$; (3) nilai signifikan interaksi penggunaan strategi dengan sikap ilmiah sebesar 0,735 dan $F_{\text {ratio }}=0.116$. Kesimpulan: (1) tidak terdapat perbedaan hasil belajar kognitif peserta didik antara pembelajaran yang menggunakan strategi pembelajaran reciprocal teaching dengan strategi pembelajaran konvensional; (2) terdapat perbedaan hasil belajar antara peserta didik yang memiliki sikap ilmiah tinggi dan sikap ilmiah rendah; (3) tidak terdapat interaksi antara penggunaan strategi pembelajaran (reciprocal teaching dan Konvensional) dengan sikap ilmiah (tinggi dan rendah) terhadap hasil belajar kognitif peserta didik.
\end{abstract}

Kata Kunci: Strategi pembelajaran reciprocal teaching, sikap ilmiah dan hasil belajar kognitif.

\section{Abstract}

This study aimed to determine whether there is : (1) The difference between the learning outcomes of students who were taught using reciprocal teaching strategies with students who were taught using conventional strategies; (2) The difference in learning outcomes between students who have high scientific attitude and students who have low scientific attitude; (3) The interaction between learning strategy with a scientific attitude towards cognitive learning outcomes. Sampling were taken two classes from tenth grade science SMAN 1 Langgudu as many as 115 students were divided into an experimental group and a control group, the first group was taught using reciprocal teaching learning strategies and the second group was taught using conventional learning strategy. Data collection was performed with techniques for cognitive achievement tests and questionnaires for scientific attitudes of students. This type of research is a quasi-experimental with $2 \times 2$ factorial design. Data were analyzed using analysis of variance technique (ANOVA) two-way with SPSS 20.0 for windows. The results of the data analysis on the significant level of 0.05 and $F_{\text {tabel }}=4$, indicates that : (1) significant value using reciprocal teaching strategies to the learning outcomes of 0.935 and $F_{\text {ratio }}=0,007$ more less than $F_{\text {tabel }}=4$; (2) the significant value of the scientific attitude of students towards learning outcomes of 0.000 and $F_{\text {ratio }}=17,157 ;(3)$ the value of the significant interaction with the strategic use of the scientific attitude of 0.735 and $F_{\text {ratio }}=0,116$. Conclusion: (1) there is no 


\begin{abstract}
difference in cognitive learning outcomes of students between learning using reciprocal teaching learning strategies with conventional learning strategies; (2) there are differences in learning outcomes between students who have a high scientific attitude and low scientific attitude; (3) there is no interaction between the use of learning strategies (reciprocal teaching and Conventional) with a scientific attitude (high and low) on cognitive learning outcomes of students .
\end{abstract}

Keywords: Reciprocal teaching learning strategies, Scientific attitude and Cognitive learning outcomes .

\section{PENDAHULUAN}

Fisika sebagai salah satu cabang Ilmu Pengetahuan Alam (sains) mengandung banyak konsep yang sifatnya abstrak. Oleh karena itu dalam pembelajaran fisika diperlukan sesuatu untuk menjembatani daya pikir peserta didik yang masih bersifat konkret agar dapat memahami konsep yang sifatnya abstrak. Dalam menyampaikan materi pelajaran, seorang guru harus mampu menggunakan berbagai model pembelajaran agar peserta didik lebih termotivasi namun tidak merugikan peserta didik. Tidaklah cukup bagi guru hanya menggunakan satu model pembelajaran atau menggunakan satu metode saja, tetapi guru dapat memilih model pembelajaran untuk mencapai tujuan pengajaran tertentu dalam proses belajar mengajar.

Dalam proses belajar mengajar keberhasilan lebih banyak ditentukan oleh tenaga pengajar. Hal ini disebabkan tenaga pengajar selain sebagai orang yang berperan dalam proses transformasi pengetahuan dan keterampilan, juga memandu jalannya proses pembelajaran. Dalam pembelajaran juga harus melibatkan suatu sistem pembelajaran yang di dalamnya terdapat subsistem-subsistem pembelajaran. Misalnya, strategi pembelajaran, media pembelajaran dan sebagainya.

Menurut Hamalik dalam Utami (2005) cara belajar seorang peserta didik sangat dipengaruhi oleh guru mata pelajaran yang bersangkutan. Pada tingkat berfikir inilah diharapkan bahwa guru, selain memberikan mengajarkan bagaimana belajar yang efisien juga berusaha untuk menumbuhkan sikap ilmiah peserta didik sehingga akan meningkatkan hasil belajar.

Untuk menghasilkan peserta didik yang mandiri dan memiliki sikap ilmiah perlu adanya suatu strategi pembelajaran yang sesuai dalam penyampaian materi pelajaran. Salah satu pendekatan yang dapat mewujudkan hal tersebut adalah strategi pengajaran terbalik (reciprocal teaching). Alasan dipilihnya strategi pengajaran terbalik dalam penyampaian materi fisika karena strategi pengajaran terbalik mengajarkan enam keterampilan kognitif yaitu membuat pertanyaan, menjawab pertanyaan, merangkum informasi-informasi penting dari jawaban pertanyan, mengidentifikasi katakata yang belum dimengerti, menjelaskan, dan memprediksi.

Berdasarkan latar belakang tersebut, dilakukan penelitian dengan rumusan masalah: "(1) Apakah terdapat perbedaan hasil belajar antara peserta didik yang menggunakan strategi pembelajaran reciprocal teaching dengan peserta didik yang menggunakan strategi pembelajaran konvensional? (2) Apakah terdapat perbedaan hasil belajar antara peserta didik yang memiliki sikap ilmiah tinggi dan peserta didik yang memiliki sikap ilmiah rendah? (3) Apakah ada interaksi antara strategi pembelajaran dengan sikap ilmiah terhadap hasil belajar kognitif?" dengan hipotesis yang berbunyi:

1. Ada perbedaan hasil belajar antara peserta didik yang menggunakan strategi reciprocal teaching dengan peserta didik yang menggunakan strategi pembelajaran konvensional.

2. Ada perbedaan hasil belajar antara peserta didik yang memiliki sikap ilmiah tinggi dan peserta didik yang memiliki sikap ilmiah rendah.

3. Ada interaksi antara strategi pembelajaran dengan sikap ilmiah terhadap hasil belajar.

Pembelajaran fisika sebaiknya diarahkan untuk menumbuhkan kemampuan berpikir, bekerja dan bersikap ilmiah serta mengkomunikasikannya sebagai aspek penting kecakapan hidup. Oleh karena itu pembelajaran fisika menekankan pada pemberian pengalaman belajar secara langsung melalui penggunaan dan pengembangan keterampilan proses dan sikap ilmiah (Depdiknas, 2005).

Terdapat beberapa strategi pembelajaran yang memberikan kesempatan peserta didik untuk aktif belajar mandiri dan mengembangkan kemampuan komunikasi matematiknya, salah satunya adalah strategi pembelajaran terbalik (Reciprocal Teaching). Menurut Palincsar dan Brown seperti yang dikutip oleh Slavin (dalam Ibrahim, 2007) bahwa strategi pembelajaran terbalik adalah pendekatan konstruktivis yang didasarkan pada prinsip-prinsip membuat pertanyaan, mengajarakan keterampilan kognitif melalui pengajaran dan pemodelan oleh guru untuk meningkatkan keterampilan membaca pada peserta didik berkemampuan rendah.

Ann Brown dan Anne Marie Palinscar dalam Utami (2005) mengemukakan bahwa dengan pengajaran terbalik guru mengajarkan peserta didik keterampilanketerampilan kognitif penting dengan menciptakan pengalaman belajar, melalui pemodelan prilaku tertentu dan kemudian membantu peserta didik mengembangkan keterampilan tersebut atas usaha mereka sendiri dengan pemberian semangat, dukungan dan suatu sistem scaffolding.

Karakteristik dari pembelajaran terbalik menurut Palinscar dan Brown (2008) adalah: "Reciprocal teaching refers to an instructional activity that takes place in the form of a dialogue between teachers and students regarding segments of text. The dialogue is structured by the use of four strategies: summarizing, question generating, clarifying, and predicting. The 
teacher and students take turns assuming the role of teacher in leading this dialogue". Bila diterjemahkan berarti bahwa karakteristik dari pembelajaran terbalik adalah (1) Dialog antar peserta didik dan guru, dimana masing-masing mendapat giliran untuk memimpin diskusi, (2) "Reciprocal" artinya suatu interaksi dimana seseorang bertindak untuk merespon yang lain, (3) Dialog yang terstruktur dengan menggunakan empat strategi, yaitu: merangkum, membuat pertanyaan dan jawaban, mengklarifikasi (menjelaskan kembali), dan memprediksi. Masing-masing strategi tersebut dapat membantu peserta didik membangun pemahaman terhadap apa yang sedang dipelajarinya.

Pembelajaran terbalik mengutamakan peran aktif peserta didik dalam pembelajaran untuk membangun pemahamannya dan mengembangkan kemampuan komunikasi matematiknya secara mandiri. Prinsip tersebut sejalan dengan prinsip dasar konstruktivisme yang beranggapan bahwa pengetahuan itu merupakan konstruksi (bentukan) dari kita yang mengetahui sesuatu. Pengetahuan itu bukanlah suatu fakta yang tinggal ditemukan, melainkan suatu perumusan yang diciptakan orang yang sedang mempelajarainya. Melalui pengajaran terbalik peserta didik diajarkan empat strategi pamahaman pengaturan diri spesifik yaitu perangkuman, pengajuan pertanyaan, pengklarifikasian (menjelaskan kembali) dan prediksi. Hal ini mendorong peserta didik menumbuhkan sikap ilmiahnya.

John W. Santrock (2003) mengungkapakan bahwa sikap ilmiah merupakan sikap yang harus ada pada diri seorang ilmuwan atau akademisi ketika menghadapi persoalan-persoalan ilmiah. Seseorang yang memiliki sikap ilmiah menyelesaikan masalah berdasarkan metode ilmiah. Sikap ilmiah terdiri dari 7 sikap yaitu; (1) sikap ingin tahu yang terlihat pada kebiasaan bertanya tentang berbagai hal yang berkaitan dengan bidang kajiannya; (2) sikap kritis yang terlihat pada kebiasaan mencari informasi sebanyak mungkin berkaitan dengan bidang kajiannya untuk dibandingbanding kelebihan-kekurangannya, kecocokan-tidaknya, kebenaran-tidaknya, dan sebagainya; (3) sikap terbuka yang terlihat pada kebiasaan mau mendengarkan pendapat, argumentasi, kritik, dan keterangan orang lain, walaupun pada akhirnya pendapat, argumentasi, kritik, dan keterangan orang lain tersebut tidak diterima karena tidak sepaham atau tidak sesuai; (4) sikap objektif yang terlihat pada kebiasaan menyatakan apa adanya, tanpa diikuti perasaan pribadi; (5) sikap rela menghargai karya orang lain yangi terlihat pada kebiasaan menyebutkan sumber secara jelas sekiranya pernyataan atau pendapat yang disampaikan memang berasal dari pernyataan atau pendapat orang lain; (6) sikap berani mempertahankan kebenaran yang nampak pada ketegaran membela fakta dan hasil temuan lapangan atau pengembangan walapun bertentangan atau tidak sesuai dengan teori atau dalil yang ada; dan (7) sikap menjangkau ke depan yang dibuktikan dengan selalu ingin membuktikan hipotesis yang disusunnya demi pengembangan bidang ilmunya.

\section{Metodelogi Penelitian}

Penelitian ini telah dilakukan di SMA N 1 Langgudu peserta didik Kelas X, dimulai dari bulan April 2014 sampai dengan bulan Mei 2014. Dalam penelitian ini yang menjadi populasi adalah seluruh peserta didik kelas X IPA SMA N 1 Langgudu yang berjumlah 115 peserta didik.

Tabel. 1. Rancangan Analisis Faktorial 2 x 2

\begin{tabular}{|c|c|c|c|}
\hline & & \multicolumn{2}{|c|}{ Strategi Pembelajaran (A) } \\
\hline & & $\begin{array}{l}\text { Reciprocal Teaching } \\
\text { (A1) }\end{array}$ & $\begin{array}{l}\text { Konvensional } \\
\text { (A2) }\end{array}$ \\
\hline \multirow{2}{*}{ Sikap Ilmiah (B) } & Tinggi (B1) & $\mathrm{A}_{1} \mathrm{~B}_{1}$ & $\mathrm{~A}_{2} \mathrm{~B}_{1}$ \\
\hline & Rendah (B2) & $\mathrm{A}_{1} \mathrm{~B}_{2}$ & $\mathrm{~A}_{2} \mathrm{~B}_{2}$ \\
\hline
\end{tabular}

Pada masing-masing kelas terdapat kelompok yang menjadi dua kelompok sikap imliah yaitu sikap imliah memiliki keterampilan sikap ilmiah tinggi dan rendah. tinggi dan sikap imliah rendah.

Dengan demikian ada 4 kelompok yaitu : (1) $\mathrm{A}_{1} \mathrm{~B}_{1}$ yaitu Pengujian hipotesis dilakukan dengan pembelajaran fisika dengan strategi reciprocal teaching menggunakan uji ANAVA dua jalur. Untuk pada paserta didik yang memiliki sikap ilmiah tinggi, (2) memudahkan perhitungan, maka ANAVA akan dihitung $\mathrm{A}_{1} \mathrm{~B}_{2}$ yaitu pembelajaran fisika dengan strategi dengan bantuan program SPSS 20. Keputusan uji: (1) reciprocal teaching pada paserta didik yang memiliki Jika Fhitung $\leq$ Ftabel, dengan taraf signifikan $0,05 \%$ sikap ilmiah rendah, (3) $\mathrm{A}_{2} \mathrm{~B}_{1}$ yaitu pembelajaran fisika maka $\mathrm{Ho}$ diterima atau $\mathrm{Ha}$ ditolak berarti tidak dengan strategi konvensioanal pada paserta didik yang signifikan. (2) Jika Fhitung $\geq$ Ftabel, dengan taraf memiliki sikap ilmiah tinggi dan (4) $\mathrm{A}_{2} \mathrm{~B}_{2}$ yaitu signifikan $0,05 \%$ maka Ho ditolak atau Ha diterima pembelajaran fisika dengan strategi konvensioanal pada berarti tidak signifikan. Untuk mengetahui perbedaan paserta didik yang memiliki sikap ilmiah rendah. mean antara kelompok sel pada anava dilakukan lanjut

Untuk mengetahui hasil belajar, peserta didik dengan menggunakan uji-t dua pihak.

diberikan tes berupa tes essay yang berbasis sikap imliah.

Sedangkan untuk mengetahui apakah peserta didik HASIL DAN PEMBAHASAN

dengan perbedaan tingkat sikap ilmiah maka akan Nilai rata-rata hasil belajar kognitif berdasarkan dilakukan penilaian sikap ilmiah dengan menggunakan instrumen tes hasil belajar kognitif peserta didik dapat angket yang bertujuan untuk membagi kelompok dilihat pada tabel berikut: 
Tabel 2. Nilai Rata-Rata Hasil Belajar Kognitif

\section{Descriptive Statistics}

\begin{tabular}{lllll}
\multicolumn{2}{l}{ Dependent Variable: HASIL BELAJAR } & & \\
\hline STRATEGI & SIKAP ILMIAH & Mean & Std. Deviation & $\mathrm{N}$ \\
\hline \multirow{4}{*}{ RT } & TINGGI & 89,0714 &, 73005 & 14 \\
& RENDAH & 80,6429 & 11,95252 & 14 \\
& Total & 84,8571 & 9,35202 & 28 \\
\hline \multirow{2}{*}{ KONVENSIONAL } & TINGGI & 88,2857 & 6,32977 & 14 \\
& RENDAH & 81,1250 & 4,63141 & 16 \\
& Total & 84,4667 & 6,50057 & 30 \\
\multirow{2}{*}{ Total } & TINGGI & 88,6786 & 4,43933 & 28 \\
& RENDAH & 80,9000 & 8,67159 & 30 \\
& Total & 84,6552 & 7,93516 & 58
\end{tabular}

Ket: RT : Reciprocal teaching

Tabel 3. Hasil analisis uji hipotesis

Tests of Between-Subjects Effects

Dependent Variable: HASIL BELAJAR

\begin{tabular}{|c|c|c|c|c|}
\hline Source & $\begin{array}{l}\text { Type III Sum of } d \\
\text { Squares }\end{array}$ & Mean Square & $\mathrm{F}$ & Sig. \\
\hline Corrected Model & $882,353^{\mathrm{a}}$ & 294,118 & 5,868 &, 002 \\
\hline Intercept & 415504,702 & 415504,702 & 8289,371 &, 000 \\
\hline STRATEGI & ,333 & ,333 & ,007 & ,935 \\
\hline SIKAP ILMIAH & 878,029 & 878,029 & 17,517 &, 000 \\
\hline $\begin{array}{l}\text { STRATEGI } * * \text { SIKAP } \\
\text { ILMIAH }\end{array}$ & 5,808 & 5,808 & ,116 & ,735 \\
\hline Total & 419246,000 & & & \\
\hline
\end{tabular}

Berdasarkan data penelitian di atas terlihat bahwa Pengetahuan itu bukanlah suatu fakta yang tinggal penggunaan strategi pembelajaran terhadap hasil belajar ditemukan, melainkan suatu perumusan yang diciptakan kognitif menunjukkan nilai $\mathrm{F}_{\text {ratio }}=0,007$ dengan angka orang yang sedang mempelajarainya (Palinscar dan signifikan 0,935. Ini menunjukkan bahwa $F_{\text {ratio }}$ lebih Brown, 2008).

kecil dari $\mathrm{F}_{\text {tabel}}=4$, maka Ho diterima dan Ha ditolak Hal lain yang terungkap dalam penelitian ini yang berarti bahwa tidak terdapat perbedaan hasil belajar adalah sikap ilmiah peserta didik memberikan perbedaan kognitif peserta didik antara pembelajaran yang hasil belajar yang signifikan, baik pada peserta didik menggunakan strategi reciprocal teaching dengan yang menggunakan strategi pembelajaran reciprocal strategi pembelajaran konvensional pada mata pelajaran teaching maupun pada peserta didik yang menggunakan fisika materi listrik dinamis. Hal ini diperkuat oleh nilai strategi pembelajaran konvensional. Hal tersebut mean pembelajaran dengan strategi reciprocal teaching berdasarkan hasil perhitungan analisis varians (anava) $(84,8)$ yang hampir sama dengan pembelajaran yang dengan menggunakan program SPSS 20 pada taraf menggunakan strategi konvensional $(84,4)$. Namun, signifikan 5\% dengan derajad kebebasan 1:57 diperoleh walaupun kedua model pembelajaran tidak memberikan $F_{\text {hitung }}$ sebesar 17,517 sedangkan $F_{\text {tabel }}$ sebesar 4 yang perbedaan hasil belajar yang signifikan, akan tetapi artinya nilai $F_{\text {hitung }}>F_{\text {tabel. }}$. Begitu juga dengan ahitung pembelajaran dengan strategi reciprocal teaching diperoleh sebesar 0,000 sedangkan $\alpha_{\text {tabel }}$ sebesar 0,05 memberikan pengaruh terhadap peningkatan hasil belajar yang artinya bahwa $\alpha_{\text {hitng }}>\alpha_{\text {tabel }}$. Ini menunjukkan bahwa peserta didik. Adanya perbedaan hasil belajar hasil hipotesis alternatif diterima yaitu adanya perbedaan hasil belajar yang lebih tinggi pada pembelajaran yang belajar antara peserta didik yang memiliki sikap ilmiah menggunakan strategi reciprocal teaching dikarenakan tinggi dan peserta didik yang memiliki sikap ilmiah strategi reciprocal teaching mengutamakan peran aktif rendah. Selain itu secara analisis deskriptif juga terlihat peserta didik dalam pembelajaran untuk membangun bahwa nilai rata-rata hasil belajar peserta didik yang pemahamannya dan mengembangkan kemampuan memiliki sikap ilmiah tinggi lebih baik daripada hasil komunikasi matematiknya secara mandiri. Prinsip belajar peserta didik yang memilki sikap ilmiah rendah. tersebut sejalan dengan prinsip dasar konstruktivisme Hal ini menunjukkan bahwa sikap ilmiah sangat yang beranggapan bahwa pengetahuan itu merupakan berpengaruh terhadap hasil belajar peserta didik.

konstruksi (bentukan) dari kita yang mengetahui sesuatu. Dalam pembelajaran fisika, sikap ilmiah ini 
tercermin dengan keingintahuan peserta didik untuk mengetahui darimana suatu konsep, hukum atau rumus fisika itu diperoleh, dan bagaimana konsep, hukum atau rumus tersebut dapat diterapkan dalam kehidupan . Selain keingintahuan peserta didik mempelajari sesuatu, 2. sikap ilmiah peserta didik juga tercermin dari tindakan kejujuran peserta didik dalam dalam belajar. Misalnya dalam mengerjakan suatu soal peserta didik selalu berusaha menyelesaikan sendiri, tanpa harus menyontek pekerjaan milik temannya. Kekritisan peserta didik dalam mempelajari sesuatu, juga merupakan bagian sikap ilmiah peserta didik. Peserta didik dalam hal ini 3. akan berusaha mengevaluasi pekerjaan. Peserta didik juga berusaha untuk mengkritisi jawaban yang dikerjakannya maupun yang dikerjakan temannya (Andersen, 1981).

Sikap ilmiah peserta didik yang berasal dari

keingintahuan peserta didik, kejujuran peserta didik, DAFTAR RUJUKAN

serta sikap kekritisan peserta didik dalam mempelajari Andersen, Lorin.w. 1981. Assessing Affective suatu pelajaran, khususnya pelajaran fisika menjadikan peserta didik dalam belajar fisika akan bersungguhsungguh tanpa ada paksaan dari pihak lain. Sikap ilimiah peserta didik inilah peserta didik akan menyenangi pelajaran, sehingga hasil belajar yang diperoleh peserta didik akan baik. Jadi semakin tinggi sikap ilmiah peserta didik dalam belajar fisika, maka hasil belajar fisika semakin baik pula. Sebaliknya semakin rendah sikap ilmiah peserta didik dalam belajar, maka hasil belajar peserta didik semakin menurun.

Adapun hal lain yang terungkap pada penelitian ini mengenai interaksi antara pembelajaran yang Santrock, John W. 2003. Adolescence 6th Edition. menggunakan strategi pembelajaran dengan sikap ilmiah, berdasarkan analisis varians dengan derajad kebebasan 1:57 dan taraf signifikansi $5 \%$ diperoleh nilai $\mathrm{F}_{\text {hitung }}$ sebesar 0,116 sedangkan $F_{\text {tabel }}$ sebesar 4 yang artinya $\mathrm{F}_{\text {hitung }}<\mathrm{F}_{\text {tabel }}$ dan nilai signifikan $\left(\alpha_{\text {hitung }}\right)$ sebesar 0,735 sedangkan $\alpha_{\text {tabel }}=0,05$ yang berarti $\alpha_{\text {hitung }}>\alpha$ tabel. Ini menunjukkan bahwa hipotesis awal diterima dimana tidak terdapat interaksi antara penggunaan strategi pembelajaran dengan sikap ilmiah terhadap hasil belajar. Hal ini diperkuat oleh statistik deskriptif rata-rata hasil belajar peserta didik yang menunjukkan bahwa adanya selisih hasil belajar yang menggunakan strategi pembelajaran reciprocal teaching dengan hasil belajar yang menggunakan strategi konvensional ditinjau dari peserta didik yang memiliki sikap ilmiah tinggi dan rendah. Dimana hasil belajar peserta lebih tinggi pada pembelajaran yang menggunakan strategi reciprocal teaching dibandingkan hasil belajar peserta didik yang menggunakan strategi konvensional baik pada peserta didika yang memilki sikap ilmiah tinggi maupun sikap ilmiah rendah. Artinya bahwapembelajaran fisika baik peserta didik yang memiliki sikap ilmiah tinggi maupun sikap ilmiah rendah di SMA N 1 Langgudu untuk pokok bahasan Listrik dinamis lebih cocok menggunakan strategi pembelajaran reciprocal teaching dibandingkan menggunakan strategi konvensional.

\section{KESIMPULAN}

Berdasarkan hasil analisis data penelitian, dapat ditarik kesimpulan sebagai berikut:

1. Tidak terdapat perbedaan hasil belajar kognitif peserta didik yang signifikan antara pembelajaran menggunakan strategi pembelajaran reciprocal teaching dengan strategi konvensional pada pembelajaran fisika materi listrik dinamis.

Terdapat perbedaan hasil belajar kognitif antara peserta didik yang memiliki sikap ilmiah tinggi dan sikap ilmiah rendah pada pembelajaran fisika materi listrik dinamis. Peserta didik yang memiliki keterampilan metakognitif tinggi memilki hasil belajar kognitif lebih baik daripada peserta didik yang memiliki keterampilan metakognitif rendah.

Tidak terdapat interaksi antara penggunaan strategi pembelajaran (reciprocal teaching dan Konvensional) dengan sikap ilmiah (tinggi dan rendah) terhadap hasil belajar kognitif peserta didik pada pembelajaran fisika materi listrik dinamis.

Characteristic in the School. Boston. Allyn and Bacon.

DEPDIKNAS. 2005. Materi Pelatihan Terintegrasi IPA Buku 3 Model-Model Pengajaran Dalam Pembelajaran Ilmu Pengetahuan Alam. Jakarta: DEPDIKNAS.

Ibrahim, Muslimin. Reciprocal Teaching Sebagai Strategi, Tersedia [Online]: http:kpicenter.org,indeks.php\%option.com_conten t\&task_view\&id 36\&itemid, [09 Maret 2014, 10:30 WITA]. Jakarta : Erlangga.

Satriawan, Muhammad,and Rosmiati 2014. Pengembangan Perangkat Pembelajaran Fisika Yang Berorientasi Pada Model Pengajaran Langsung Pada Materi Entropi Dan Perubahannya”. Open Science Framework. November 22.

Palincsar. Reciprocal Pengajaran, Tersedia [Online]: http://teams

www.ncrel.org/sdrs/areas/issues/students/atrisk/at 6lk38.htm-8k- [09 Maret 2014,14:00 WITA].

Utami, Sri. 2005. Penerapan Strategi Pengajaran Terbalik Pada Mata Kuliah Biologi Umumdi Progaram Study Matematika STKIP-PGRI Tulungagung. Tesis Magister Pendidikan. Surabaya: Program Pascasarjana Progaram Studi Pendidikan Sains Universitas Negeri Surabaya. 